\title{
The Riddle of Racial Difference in anne Garréta's Sphinx
}

\section{Citation}

Kim, Annabel L. 2017. “The Riddle of Racial Difference in Anne Garréta's Sphinx.” Diacritics 45 (1): 4-22. doi:10.1353/dia.2017.0000.

\section{Published Version}

doi:10.1353/dia.2017.0000

\section{Permanent link}

http://nrs.harvard.edu/urn-3:HUL.InstRepos:34858100

\section{Terms of Use}

This article was downloaded from Harvard University's DASH repository, and is made available under the terms and conditions applicable to Open Access Policy Articles, as set forth at http:// nrs.harvard.edu/urn-3:HUL.InstRepos:dash.current.terms-of-use\#OAP

\section{Share Your Story}

The Harvard community has made this article openly available.

Please share how this access benefits you. Submit a story.

Accessibility 
[Johns Hopkins University Press allows authors "to include the Article in your own personal or departmental institutional database or on-line site" provided that it is "the final manuscript version of the Article only, not the final published version in any format."]

Copyright (C) 2018 Cornell University. This article first appeared in Diacritics, Volume 45, Issue 1, January, 2017, pages 4-23.

\section{THE RIDDLE OF RACIAL DIFFERENCE IN ANNE GARRÉTA'S SPHINX} Annabel L. Kim

In April 2015, with the publication of the English translation of her first novel, Sphinx, the French novelist Anne Garréta became accessible for the first time to an Anglophone readership. When it was first published in 1986, this love story, which tells of the tragic encounter between a nameless young theology student turned DJ and A***, an African American cabaret dancer, erupted onto the French literary scene. The novel astonished its readers through the virtuosic feat of keeping its protagonists' genders completely indeterminable - Garréta, then a twenty-three-year-old normalienne, had scrubbed the French text of all marks of gender. ${ }^{1}$ Critics, both then and now, have marveled at this complete erasure of gender, even as they have overlooked Garréta's other treatment of difference - the emphasis on racial difference that accompanies her systematic effacement of sexual difference in the novel.

The love story is traditionally understood as requiring difference, in the broadest sense of the term, given that the whole point is that love joins two (or more) individuals. In Garréta's iteration of the love story, however, she erases sexual difference and presents race as the difference that love can then reconcile or traverse: her love story features the relationship between a white European and a black American. This raises the question of why erasing sexual difference should either produce or expose racial difference when the novel was written to express the principle of "fuck difference," as Garréta shared with me in a March 2013 interview in Paris. ${ }^{2}$ While the difference Garréta denounces is sexual difference, which she considers to be fetishized dogma, and not racial difference, it seems inconsistent and politically incoherent to decry one form of fetishized difference while promoting another when the problem surrounding difference is precisely the 
process by which it assumes the status of a concept around which an entire social order can be organized. I see this statement as applying more broadly to all fetishized difference that has been solidified into identity even if the original statement was narrower in its scope. Accordingly, a careful examination of what may be read as a caricatural treatment of racial difference will show that Garréta's seeming instrumentalization and exploitation of race for the purposes of destroying sex, or gender, are actually consonant with what I see as her larger project of writing against difference tout court, an investment that we can trace to the major influence of the French writer and theorist Monique Wittig on her own writing and thought. In other words, if Garréta seems to build up racial difference in Sphinx, it is only to tear it down after having shown how such difference is built up through language in the first place.

\section{LANGUAGE AND RESISTANCE}

Michel Foucault has taught us that discourse has the power to create identity. His La Volonté de savoir (The History of Sexuality: An Introduction), the first volume of his unfinished Histoire de la sexualité, argues that the homosexual did not exist as such until the category of the homosexual was created by sexologists and began to circulate in discourse. This and other identity categories were thus effects of discourse rather than its cause. Thanks in large part to feminist and queer theories informed by Foucault's insights, the idea that identity is discursively constructed with nothing natural about it is now commonplace. While we are quick to recognize the force of discourse, however, it is not so clear how it comes to have that force - the power to ossify difference and create categories such as sex and race. Discourse is language that has been fixed into a function. But how does language become discourse? And how does it become fixed?

As a mode of writing that programmatically claims to reflect the world it describes, literary realism often does little to strip discourse down to language in a way that would allow readers to question the gendered norms that have become thoroughly embedded into social practice. ${ }^{3}$ In the conventional realist novel, language only exists in an already socialized form and is thus unfit to do the work that Wittig describes 
in Le Chantier littéraire (The literary workshop), her posthumously published ars poetica, of stripping words of the social significations that have sedimented onto them. Language must be stripped of the history of its social usage, thus allowing words to return to their pure materiality, with language in its raw, pre-signifying state, before it has been mobilized around some ideological or conceptual purpose. ${ }^{4}$ Wittig calls for teasing language apart from discourse in order to tap into the radical political potential to be found in turning to language, rather than discourse, as a site for new meaning. Precisely for this reason, Garréta, like Wittig before her, treats the experimental (as opposed to the conventional) novel as a cultural form where discourse and language can be played against each other. The self-awareness of the experimental novel's literary language calls attention to the materiality of language. ${ }^{5}$ Because the novel must also reference the world outside itself in order to make good on its promise of a textual simulation of lived reality, or a textual experience of an unlived reality, it also calls attention to itself as discourse. This double function gives the novel an advantage over theoretical texts as the means for working with, on, and against language to work against identity and the difference that founds it. ${ }^{6}$ It is the novel that has the potential to effect change, reader by reader, by undoing those categories that seem to make sense of reality and order the world in a necessary way. In short, it is the novel, and not theory, that functions as a Trojan horse, the figure Wittig uses to explain how a literary text "can operate as a war machine upon its epoch," an epoch marked then, in the 1980s, as it is now, by difference. ${ }^{7}$

Garréta sees herself writing "after" Wittig in a double sense_-after Wittig chronologically and after her in the sense of deriving inspiration from Wittig's writing:

Monique Wittig is an extremely important writer to me. In a way, she made it possible for me to write my first novel, Sphinx, which attempted to take literally what she means when she says that it is necessary to eliminate and destroy the mark of gender in language, and that this can only happen through exercising language itself.

I thus have a debt that is not a debt but that obligates me nonetheless - it isn't that I owe something to Monique Wittig, but that she opened up a possibility for me. So it is important to me that I continue to pass on something that I think she offered to me, that I have not found except in her. I am absolutely committed to this. ${ }^{8}$ 
In her homage to Wittig, Garréta offers up a paradoxical characterization of her debt as "not a debt," but something that still has the weight of obligation, even if she does not think of the obligation in terms of owing, but of compelling possibility. In this, Garréta reconceptualizes debt as something that no longer puts the debtor in a position of having to give up something of herself in proportion to the value of what she has received, giving the creditor influence over the debtor. Garréta understands her debt to Wittig as a liberating possibility that is conceived of in terms of something that can be passed on to others to do with as they please. Her obligation does not mean hewing to Wittig's way of experiencing this possibility; rather, it obligates Garréta to become Garréta. This debt demands creativity rather than conformity.

Garréta's obligation is to do something with this possibility of using language to undo difference, to attempt to free others from the categories of identity that are embedded in language — and that are made of and by language. As Wittig explains, rather than having language do things to you, you must begin doing things to language:

The ontological farce that consists of trying to divide a being in language by imposing a mark on her, the conceptual maneuver that wrests away from marked individuals what rightfully belongs to them-language - must cease. It is necessary to destroy gender entirely. This endeavor can be entirely accomplished through the use of language. ${ }^{9}$

The same language that genders women and marks them as particular can also destroy that mark of particularity, provided one knows how to make it do so. Wittig uses the lesbian subject to displace the universal male subject implied by the unmarked term through her work on pronouns as we see in her revisions of the récit d'enfance (childhood narrative) in L'Opoponax (1964), where Wittig exploits the indeterminate nature of the pronoun on to dismantle the gendered bildungsroman and universalize a young lesbian's point of view. She reworks the epic in Les Guérillères (1969) by expanding the feminine third person plural elles to represent all humanity instead of the specificity of groups of women. Reworking lyric love poetry in Le Corps lesbien (1973, The Lesbian Body), she works upon and breaks down the je and tu to establish a relationship of intersubjectivity and interlocution that is based on an absolute reciprocity and interchangeability between the 
first- and second-person pronouns that are normally distinct. In Brouillon pour un dictionnaire des amantes (1976, Lesbian Peoples: Material for a Dictionary) and Virgile, non (1985, Across the Acheron), she defamiliarizes such familiar texts as Dante's Divine Comedy and the standard dictionary by overturning their androcentric perspectives.

Through these works, Wittig demonstrates that genre as literary genre has been built on genre as gender. Garréta similarly defamiliarizes genre by taking the traditional love story, the seemingly ageless articulation of heterosexual desire, and removing gender from the equation. She works with the possibility opened up by Wittig and makes it hers by replacing Wittig's lesbianized subject with her own project of rendering the subject indeterminable and undifferentiated. But, as we will see, Garréta experiments not only with sex but also with race, and the project of indeterminability is brought to bear on both categories. It is precisely Garréta's experimentation with sex and race - where the first is somewhat expected when it comes to deconstructing difference through language, while the latter is unexpected - that makes the novel so important. Let us turn now to Sphinx to see the kind of work Garréta does on and to language — work that shows race to be as unnatural a category as sex and makes the text's racial differentiation ultimately serve her project of indifferentiation and indeterminacy.

\section{A RACIST SPHINX?}

Sphinx was written and published well before Garréta was inducted into the Oulipo in $2001^{10}$ and before she became known in academic circles for her familiarity with American approaches to queer and gender studies. Nonetheless, Sphinx anticipates what was to become Garréta's expressed investment in writing within the constraints for which the Oulipo is known, and it exposes the discursive formation of identities that would become a key insight of queer theory.

Garréta's future intellectual positions are already apparent in Sphinx. The language of the novel does away with sexual difference by refusing to reveal the sexes of the protagonists. The reader is given no clues 
as to whether the relationship is between two men, two women, or a man and a woman. Were she writing in English, she would be writing a novel without using he or she, him or her. In French, subject pronouns, adjectives, compound past tense verbs, and direct object pronouns can all indicate gender, so Garréta carefully avoids these parts of speech and privileges the infinitive, imperfect, and preterit passé simple over compound tenses, indirect objects over direct objects, and impersonal, passive constructions in place of the gendered subject pronouns il and elle.

If the result is surprising in English translation, it is even more so in French. Writing against what seems to be the naturally gendered grain of French, Garréta also resists the naturalness of bodies and their sexed nature. This carefully wrought withholding of deterministic language exposes the constructed nature of identity, or what Judith Butler describes as performative identity, ${ }^{11}$ a notion that would be popularized by queer theory. It seems hardly a coincidence that A***_ who calls to mind Josephine Baker, another African American cabaret dancer who was a master of turning identity into a performance on her Parisian stagesand the narrator, as a DJ, both inhabit the novel as part of the performance industry. From the very beginning, Garréta keeps her protagonists' identities indeterminate when it comes to their sex and sexuality, thus setting her readers up to think of identity as something performed, not something fixed that can be ascertained.

Garréta refuses to let her protagonists' bodies bear the mark of sexual difference. A sexual encounter would be the ultimate occasion for either ascertaining sexual difference, in the case of heterosexual encounters, or for disavowing it, as in the case of homosexual ones. ${ }^{12}$ In Sphinx, however, the body remains stubbornly illegible in terms of its sex:

J'ai dans la bouche, encore, le goût d'une peau, de la sueur sur cette peau. Contre mes mains l'impression tactile que me firent et cette peau et le modelé de cette chair. . . . Je ne saurais raconter précisément ce qui advint, non plus que décrire ou même faire mention de ce que je fis ou de ce dont je fus l'objet. . . . Sexes mêlés, je ne sus plus rien distinguer. ${ }^{13}$

I have in my mouth, still, the taste of skin, of the sweat on that skin; against my hands, the tactile impression of skin and the shape of that flesh. ... I don't know how to recount precisely what happened, or how to describe or even attest to what I did, what was done to 
me. . . Our sexes mingled, I no longer knew how to tell anything apart. ${ }^{14}$

The sexed nature of bodies in sexual encounters is occluded by treating the body as unspecific skin, flesh, and sweat, and by disregarding genital specificity to articulate instead the confused nature of the coupling. Illegible in terms of its sex, the indeterminate and protean body can reflect whatever the reader desires it to be. The title Sphinx evokes this indeterminacy by referencing the impossibility of knowing, or in this case, the impossibility of figuring (out) the body and giving it an identity. Falling into an identitarian trap, reviewers have tended to read the relationship in Sphinx as heterosexual or homosexual depending on their own sensibilities. Finding it difficult to suspend certainty and commit to indeterminacy, they have assumed there must be some form of sexual difference (or identity) that Garréta had intended to write into being. ${ }^{15}$

This striking feat of her sustained refusal of sexed bodies is accompanied by a less spectacular, perhaps, but equally significant recoding of the bodies in question in terms of race. The novel identifies the narrator as white and $\mathrm{A} * * *$ as black: “J'appris qu'une peau noire telle celle de $\mathrm{A} * * *$ exigeait un maquillage d'une tout autre teinte et d'un tout autre dessin qu'une peau blanche" (I learned that black skin like A***'s demands makeup of a completely different hue and variety than white skin) $(22 ; 9)$. In the absence of sexual difference, racial difference is introduced, as if bodies still have to be differentiated one way or another for their connection to be meaningful. In Sphinx, A***'s black body signals both racial difference and cultural difference. A*** is not simply given a black body as a black iteration of the French citizen. The character is not French or Francophone but foreign, which, in this context, means American. A*** and the narrator therefore have different languages as well as different skin tones, and they come from different places. While removing sexual difference, then, Garréta has nonetheless doubled difference. She has inscribed the bodies of both $\mathrm{A}^{* * *}$ and the narrator with race, a difference embedded in a narrative of biological essentialism that translates greater or lesser levels of melanin and pigment into the concepts of blackness or whiteness. She has also inscribed their bodies with the purely cultural difference of nationality. A body does not announce its Frenchness any more than it announces its Americanness, but in Sphinx Garréta has tied this cultural difference 
to racial difference. However, these categories of identity do not carry equal semiotic weight in the novel.

In the second half of the novel, the cultural difference manifest in the language and customs of A***'s

American family, which stands in for black America at large, assumes principal importance. Once they

become lovers, the narrator and $A * * *$ go to Harlem and then visit $A * * *$ 's extended family somewhere in either Long Island or New Jersey. The narrator describes the experience of conversing and eating soul food

with this family as a profound experience of feeling at home:

Il me semblait être là chez moi, tant ils surent me donner l'impression d'appartenir à leur famille, oubliant sans effort la différence de race, de couleur, de civilisation, de classe et tout ce que l'on voudra bien pointer et accentuer parmi les traits possibles d'altérité. Il me semblait avoir toujours entendu cette langue qu'ils parlaient entre eux, avoir depuis toujours mangé de cette même nourriture qu'ils m'offrirent.

Et les vieilles mammas noires riaient de plaisir à me voir manifester un tel appétit. A***, qui toujours me vit, à l'endroit des nourritures terrestres, faire montre d'ennui ou d'indifférence, s'étonnait et se réjouissait. Il semblait que j'oubliais de dépérir, que je goûtais enfin à la vie, que j'y mordais sans l'entremâcher de paroles, propos de table qui, en Europe assez généralement et en France en particulier, constituent la substance essentielle des dîners. (88)

I felt at home there, so much did they make me feel like a part of their family, effortlessly forgetting our differences in race, color, culture, class - everything that one might cite as possible traits of alterity. It was as if the language they were speaking and the food they were cooking had always been familiar to me.

And the old black mommas laughed with delight to see that I had such an appetite. A***, who was used to seeing me bored or indifferent when faced with earthly sustenance, was astonished and overjoyed. It seemed that I was forgetting to waste away, that I was finally tasting life, that I was biting into it without words getting in the way, those tableside conversations that, in Europe generally and France in particular, constitute the essential substance of meals. (63)

Here, Garréta's narrator figures the alterity of African Americanness as able to do away with all alterity. Black America's culture and dialect — which the narrator finds as familiar as French — is the means of forgetting or transcending alterity and tasting the freedom to be oneself regardless of color, creed, class, etc. The narrator casts black language as naturally resistant to difference in a way that French is not. I contend that it is no accident or contradiction that in her attempt to erase difference, Garréta, through her narrator, appears to 
shore up African American difference as somehow exemplary and salvific.

This turn toward black America shifts the focus away from biological expressions of racial difference, emphasizing instead cultural and especially linguistic expressions. Indeed, it would appear that Garréta has bundled the biological with the cultural in order to approach the question of racial difference through language and, in this way, to insist that this other difference, like sexual difference, also be approached in terms of language. Where Garréta deploys language as a means to undo sexual difference in French, the narrator privileges black language as the site where the desire for hybridity, for a fluid identity liberated from the strictures of fixed difference, is best realized. In the description of eating soul food with A***'s family, what comes to the fore is not the difference between cuisines so much as the difference in languages. For the narrator, meals centered around soul food do not require the sort of conversation, that is, language, that a French meal does; in the narrator's telling, conversation around the French dinner table invariably diminishes one's appetite for life. The primary difference between the two cultures represented by the pair of lovers is thus linguistic, and language will consequently be the means of turning the categorical oppressiveness of French, and its embedded difference, against itself.

However, one has to question Garréta's use of a caricatural image of black America in a novel dedicated to blurring identity and destroying the foundational difference of identity categories. Why does she perpetuate any stereotypes of racial alterity, even if to combat other stereotypes? Indeed, Garréta's use of a worn-out stereotype such as the "old black momma," uncomfortably close to the mammy figure, would seem to legitimate an unquestionably crude form of difference. This is especially remarkable coming from a feminist who uncompromisingly rejects the notion of essential difference. Garréta's call to "fuck difference" is most powerful if it is not a watered down version of feminism that objects to one form of difference but tolerates another.

It is completely possible that Garréta's anti-difference ethos, which aspires to the universal in the absoluteness of its declaration, in fact depends on a fetishization and instrumentalization of blackness- 
universalism, as we know all too well, often turns out to be an oppressive, supremacist particularism. It may be that Sphinx is in fact very much a text of its time: the 1980s was a moment when the inconsistencies and racist blind spots of second-wave feminism — i.e., "white" feminism — became all too apparent (as seen in the necessary critique performed by intersectionality). ${ }^{16}$ It is possible that Garréta's anti-difference ethos has itself evolved over the decades from one that targeted gender and sexuality at the expense of race to one that is more explicitly anti-racist. ${ }^{17}$ All these interpretations are possible, but I intend to posit another one, which makes Sphinx politically potent today, so that the novel is not simply an artifact of less enlightened times.

From an apparent fetishization of blackness, coupled with the caricatures and stereotypes that pop up throughout the novel, it would be easy to cast Garréta as a writer insensitive to matters of race, but such a reading conflates Garréta with the narrator. Given that Garréta is undeniably behind the scrubbing of gender difference in the novel, it is tempting to confuse Garréta with the narrator and, when it comes to race, attribute that same intentionality to Garréta rather than to the problematic character of the narrator. If I insist on distinguishing between Garréta and her narrator - as I did in my discussion of the family dinner - to attribute the problematic treatment of race to the latter, it is not merely to perform a recuperative reading of or apology for Garréta. On a number of fronts, I believe it makes the most sense and results in the most productive reading to distinguish Garréta's narrator from Garréta herself. First, if we take seriously Garréta's debt to Wittig, it is logical to treat the novel as a hollow text, a Trojan horse, instead of adopting the perhaps more obvious reading, in which Garréta's twenty-three-year-old self's feminist politics turn out to be not particularly developed, as evinced by a deeply problematic conceptualization of race. This reading, which requires no interpretation because of its obviousness, turns the text into a solid rather than a hollow object. Second, the less facile reading, beyond being consonant with the Wittigian mode of writing a literary text as a Trojan horse that contains something very different than what its equine form promises, integrates Sphinx with the rest of Garréta's corpus, which can be described as radically anti-identitarian and antidifferentialist. ${ }^{18}$ Garréta's first novel can thus be read alongside and with the novels that follow rather than as 
a one-off that does not belong with the rest of her literary production. And last, Garréta's entire corpus demonstrates that she is anything but an easy or transparent writer.. Her novels are meticulously constructed, and reading them requires work — they are not beach reading, easily consumed. ${ }^{19} \mathrm{~A}$ simplistic reading of Sphinx — without the necessary labor to attend to Garréta's own labor in creating the novel—will miss the revelation that the novel is anything but racist: it grapples directly with the problem of racism in order to enjoin the reader to dismantle both racial difference and sexual difference.

Before proceeding with an analysis of the complex construction of Garréta’s deconstructive work, I want to first address the enormous riskiness of Garréta's Trojan horse venture. I am making a case for seeing Garréta's deployment and construction of racial difference as a means to tear it down, but such a reading requires labor. Returning to the astounding blindness to race that Sphinx's readers have demonstrated, the critical reception I mentioned at the beginning of this article is a perfect example of what happens when you don't read laboriously. Instead of a powerful "fuck difference" ethos that articulates a radical political vision of a new sociality unordered and unfettered by any form of difference, an effortless reading may lead to a celebration of the dissolution of sexual difference at the cost of tacit acceptance of racial difference, and not just any racial difference, but a racist one. In other words, this reading results in a "white feminist" text that does more harm than good in promoting the idea that some invidious forms of difference must be tolerated for the sake of abolishing another. These are the high stakes of Garréta's novel, and we can certainly debate whether or not it's worth the risk. In what follows, I will show what happens if we do put in the work to activate the Trojan horse of Sphinx.

\section{THE LABORS OF SPHINX}

To read Sphinx laboriously is to read Garréta's deployment of racial stereotypes critically as the means of ironically calling attention to the way the narrator turns cultural differences into natural differences as they are attached to certain bodies. Following this line of thinking, we could say that Garréta uses fiction in much 
the same way Étienne Balibar uses political theory, to argue that "biological or genetic naturalism is not the only means of naturalizing human behaviour and social affinities. . . [C]ulture can also function like a nature, and it can in particular function as a way of locking individuals and groups a priori into a genealogy, into a determination that is immutable and intangible in origin." ${ }^{20}$

In other words, Garréta's apparent investment in racial difference is an ironic one, and the reinforcement of racial difference that accompanies the radical destruction of sexual difference serves as a decoy for difference that reveals itself as hollowed out. This irony, which is hardly obvious or self-evident, can be seen in the narrator's description of black American dialect:

L'anglais que je parle a gardé les stigmates de cette fréquentation presque exclusive des Noirs. Imperceptiblement, des expressions, des incorrections caractéristiques de leur parler se sont glissées dans le tissu de langue académique qu'on m'avait enseignée au lycée. Cela, depuis, m'a été un trouble dans mes conversations : cette langue que je parle est un hybride monstrueux; j'ai mêlé Oxford et Harlem, Byron et le gospel. (89)

My English still bears the stigmata of keeping company almost exclusively with black people. Imperceptibly, the expressions and characteristic improprieties of their speech slipped into the tissue of the academic English I had been taught in high school. This has disrupted my conversations: the language I speak is a monstrous hybrid, mingling Oxford and Harlem, Byron and gospel. (64)

Garréta here doles out the clichés: of course black American English is riddled with ungrammatical variations on standard English, of which the most correct iteration is to be found at Oxford; of course the most obviously black idiom is gospel music, and it goes without saying that Harlem is the purest iteration of black American culture. This characterization is disturbing in its racial insensitivity and caricatural treatment of American black culture, but I would argue that Garréta does so in order to parody facile caricatures, rather than to reproduce them uncritically.

The obvious reading of Garréta that takes this passage at face value reproduces a fetishistic view of blackness. Black American language - the sign that turns racial difference into cultural difference and naturalizes the distinction between them - is the guarantor of hybridity and subversion. It undoes English by 
undermining the correctness of white, Anglo-Saxon, Puritan English. According to this reading, Garréta's grounding of the novel's anti-difference enterprise in an essential black language is a concession made in the name of eliminating sexual difference, the seemingly universal difference that cuts through other differences such as race and class. The marginal status of black English leads directly to the fetishization of black culture and desire for the black body. Following this logic, the narrator sees in blackness the perfect medium for being able to break up fixed categories of identity, but the price for such destabilization is the fixing of blackness.

While the French language fixes difference with its gendered grammar, black African American language counteracts that fixity through soul. The narrator claims: "Mon Amérique à moi est noire: sa musique, ses voix, sa nourriture. Noires, il y a un terme pour cela, soul: soul music, soul food" (My America is black: the music, the voices, the food. These black things have a name, soul: soul music, soul food) (87; 62). Black culture, refracted through soul, provides Garréta with the possibility of a language that is not beholden to the subordinating logic of French. Blackness comes to stand in for an identity that is more American than the soulless, sanitized Americanness of what the narrator describes as "l' Amérique blanche, anglo-saxonne et puritaine" (white, Anglo-Saxon, Puritan America) (87; 62). Black Americanness consequently permits a greater distance from French and from France, whose "universal" citizen is configured as white, heterosexual, and male. By contrast, black skin, black language, and black culture exemplify a language that offers a promised land of freedom and equality. The narrator's desire for a differently racialized body is not so much the desire for a different kind of body as it is the desire for a language and culture less dependent on difference than French language and culture. Black language provides a model for what Garréta is trying to do with French, that is, to undo its gendered and gendering operations. While this racializing might be positive in its valence of a certain black superiority, it remains grounded in an essentializing difference. One form of difference is swapped out for another, and we wind up right where we began, stuck in difference.

The true allegory of Sphinx is not the allegory of black alterity as a difference that might create more 
fluid ways of being human; it is an allegory of the invidiousness of all forms of difference. To read Sphinx laboriously, to read it as a complex text, we have to reject the narrator's reading of race as the allegorical production of a better kind of alterity. Rather than be taken in by a difference that promises to transcend other differences, Garréta rejects racial difference as the lure that would lead the reader back into the trap of difference. Garréta's polarized stereotypes and the caricatures they form offer parodic representations of black language that are not meant to be swallowed whole, taken as they are. A necessary condition of the Trojan horse is that it resembles closely enough the object it claims to be - a statue of a horse, in the Trojans' case, a racist and reductive rendering of blackness, in Garréta's - in order to be let inside the city walls (the reader's mind) to launch its attack. That is, for Garréta to reject racial difference as the lure that would lead the reader back into the trap of difference, it must first be able to pass as an alluring difference.

Garréta's attention to the language of black difference, which assumes a more important role than black skin, points to the crucial role language plays in creating and reifying forms of difference. When she places language that eliminates sexual difference in relation to language that shores up racial difference, Garréta exposes the equally constructed nature of these differences. By bundling racial difference with cultural difference, she shows how easy it is for us to slide from the cultural, to the biological, to the essential. The social order has primed us to identify difference and then compels us to perform it. Once the reader sees Garréta's use of stereotypes for what it is, it becomes difficult if not impossible to accept her construction of blackness. This leads us to examine the tendency to bundle differences, as if we could impute a more complex identity to individuals by doing so. Why, she forces us to ask, must we insist on transforming bodies into signs? According to this reading, in distinction to her narrator, Garréta is saying that bodies are not simply meant to be read and identified so much as to be lived in. In a Foucauldian gesture, she invites us to consider her novel as the site for new "bodies and pleasures." 1

Garréta challenges her reader to resist the instrumentalization of bodies that occurs when we inscribe them with difference through signifiers of identity. Rather than giving us access to richer, fuller subjectivity, 
difference deadens our subjectivity, quite literally, in Sphinx: A*** dies tragically, as does A***'s mother, and with them, the kinship structure based on the redemptive difference ironically described in Sphinx, and the salvific relationality it contained. In a nod to the seventeenth- and eighteenth-century novels that are Garréta's academic specialty, she ends this novel by also murdering her narrator, as if to say that the narrator must pay for the knowledge that may have been gained. ${ }^{22}$ Reading Garréta, the early modern specialist, with these eighteenth-century heroines in mind, her killing both the narrator and the narrator's love object can be read as a repudiation of knowledge and a warning against the kind of misleading knowledge that identity, founded in difference, is mistakenly thought to provide. Both race and gender exemplify such a promise of knowledge, where a person is knowable or known, where being identifiably something makes one identifiably someone. In Sphinx, the spectacular removal of gender and the display of race work together simultaneously to make clear the extent to which we, as socialized subjects, equate knowledge with identity. Indeterminacy, as enacted in the novel, is preferable to the fatal determinacy of presuming to know. For the anti-identitarian Garréta, literature is the site of not knowing rather than the site of revelation.

We can also view the death of the narrator as an inevitable consequence of a writerly commitment to a certain vision of the aesthetics of literature, which is what Jacques Rancière argues in his essay, "Why Emma Bovary Had to Be Killed.”23 In Rancière's analysis of the relationship between Flaubert and Emma, Emma must die because she betrays the novelist's aesthetic by trying to translate the pure sensations captured by literature into a concretely pretty, pedestrian life. Because Emma tries to concretize the aesthetic experience she finds in literature and incorporate it into her life by buying trinkets, furniture, and dresses, thereby missing the point of literature, she must be killed to teach the reader a lesson about literature. In Garréta's case, the aesthetic stakes concern difference, not literariness. Garréta's narrator's death reprises Emma's death at Flaubert's hands, insofar as it serves as a warning to the reader. The narrator of Sphinx is shown to be invested in the aesthetics of difference, retaining racial difference in the narrative despite getting rid of sexual difference. In this, the narrator betrays Garréta's literary vision of freeing experience and 
sensation from the identitarian categories through which they are understood and processed, and has to be killed.

\section{New Forms}

Perhaps it is no coincidence that Garréta, like Wittig, chooses a sculptural figure as her operative metaphor: the mythical sphinx is best known to us through its sculptural representations, and the Trojan horse was able to function as a war machine because it was received as a wooden sculpture, as a work with aesthetic qualities. Existing in three dimensions, the sculpture's form and materiality are apprehended immediately, while the medium, be it stone, or wood, or metal, is recognized as raw material, or "matériau brut" as Wittig puts it, that has been worked. ${ }^{24}$ With a title associated with the sculptural, Garréta insists on the importance of form for literature, an idea foundational to Wittig's theorization of the literary text as a Trojan horse, a war machine that "pulverize[s] the old forms and formal conventions." ${ }^{25}$ Wittig's logic and literary practice manifest her conviction that the pulverization of old forms and formal conventions can lead to the pulverization of social forms and conventions as well. This vision of a political literature is distinct from socalled committed literature for its attention to literary form and its drive to work on language in innovative ways: for Wittig, the use of language is itself an immanently political act, and literary work on language, or aesthetic work, has a political dimension. This coming together of the political with the aesthetic, or literary, can be seen in Sphinx, in Garréta's work against difference and in her stance of "fuck difference." Garréta's mobilization of the novel to engage in literary formal experimentation that does this political work of dismantling identity follows Wittig's interpretation of Marcel Proust.

Wittig characterizes À la recherche du temps perdu (In Search of Lost Time) as a Trojan horse that infiltrated a straight Parisian society and homosexualized it; the act of reading forced Proust's readers to acknowledge that despite themselves, the novel was constituting a homosexual subject as undeniably real. In order to read the Recherche, they had to assume Proust's homosexual point of view as their own and enter fully into the 
work's homosexualized textual reality. Through literature, Proust was able to alter the terms through which an entire social order viewed itself, making the straight world and the straight mind interpellated by Proust no longer quite so straight. ${ }^{26}$ If Proust had this effect, Wittig maintains, it is only because he used his artistry to universalize his particular, homosexual point of view and present it so that it could take the place traditionally occupied by the universal straight white male. Wittig explains what it took for Proust to get his Trojan horse past the walls of Parisian society:

History, I believe, intervenes at the individual and subjective level and manifests itself in the particular point of view of the writer. It is then one of the most vital and strategic parts of the writer's task to universalize this point of view. But to carry out a literary work one must be modest and know that being gay or anything else is not enough. For reality cannot be directly transferred from the consciousness to the book. The universalization of each point of view demands a particular attention to the formal elements that can be open to history, such as themes, subjects of narratives, as well as the global form of the work. It is the attempted universalization of the point of view that turns or does not turn a literary work into a war machine. ${ }^{27}$

For Wittig, the literary work emerges through the particularity of the writer's point of view. For the work to shape the world, however, to "operate as a war machine upon its epoch," it cannot stay particularized: the literary work must open up onto something larger.

Ultimately, Garréta's novelistic experiment in indeterminability operates more as a Trojan horse than as a sphinx, which serves as the guardian of thresholds, determining who can or cannot pass. Instead of drawing in certain readers and ignoring and blocking others, Garréta's literary language constructs the novel as a universalizing war machine. Rather than homosexualize the reader, as Proust does, or lesbianize the reader, as Wittig does, Garréta's novel confronts the reader with an indeterminable identity. At first, there appears to be a difference to rally around_ - racial difference — but that difference functions as a Trojan horse. Just as the original Trojan horse is a sculpture that announces its facture, its materiality, Garréta's novelistic Trojan horse shows that it is made of language. If Garréta demonstrates that language creates difference as it becomes discourse, she then asserts that discourse, and hence difference, can be returned to language by destroying sexual difference and hollowing out racial difference. In doing so, she gestures toward a Wittigian 
universalism that sees literary language as the means by which the writer might "tear open the closely woven material of the commonplaces, and . . continually prevent their organization into a system of compulsory meaning." 28

Sphinx rejects the idea of insurmountable difference or differences and supersedes individual identity in order to create new forms of indeterminacy that address everyone and no one in particular. As Wittig sees it, if a novel is to have political impact and staying power as literature, it must be able to speak to all readers: it cannot screen readers for whatever configuration of differences would constitute an ideal reader — it cannot be a gay novel, or a feminine novel, or a black novel. For Garréta, as for Wittig, this universalization is able to come about in the novel precisely as it permits readers to reenact the writer's task of separating language from discourse. Through the act of reading a Trojan horse, the reader is able to break open the particular categories discourse creates and circulates, to access language as language, in all its potential. Sphinx invites us to disallow identity as a valid concept despite how costly it may be to do so. It overdetermines racial identity to show the reader that the inability to determine identity is preferable to fixing it.

I want to end by returning to the scene where Garréta stages a sexual encounter while refusing sexual difference. In this dark novel of loss and punishment, where the protagonists' sexual indeterminateness is not able to eradicate the sexed and raced nature of society, that scene stands out as a rare, utopian suspension of the compulsory difference of the social order. As the narrator describes the combining of bodies, seeking to recall the feeling of indeterminate flesh against indeterminate flesh, not only is sexual difference refused, but — so subtle as to be easily overlooked — racial difference disappears as well. ${ }^{29}$ In this sexual encounter where the narrator and $\mathrm{A}^{* * *}$ are rendered equal, where both act and are acted upon ("ce que je fis . . . ce dont je fus l'objet"), Garréta, who first evokes the protagonists' skins in racialized terms, refrains from doing so in describing this contact of black skin against white skin. This places the scene firmly under the sign of "fuck difference," driven by a vision where race, far from being fetishized or reified, is also to be dismantled. 
This scene gives us a glimpse of a world in which we do not consent to difference, where we are able to experience and encounter an other without structuring that experience through readymade concepts. Where Foucault's utopian gesture in The History of Sexuality imagined bodies and pleasures that operate outside the "austere monarchy of sex," ${ }^{30}$ Garréta's is even more expansive, envisioning the overthrow of that other austere monarchy, the monarchy of race. The hope is that we will not consent to be subjects of a monarchy that does not serve us and instead refuse familiar scripts for identities that limit us to a predetermined set of possibilities. Just as Foucault does not offer a blueprint for how to overthrow the monarchy of sex, Garréta does not offer instructions for how to overthrow sex and race. She instead creates a horizon of possibility and shows us that however we get there, if we ever get there, it will have to be through language, through working to break down and let go of the well-worn language that has made us who we are so that we might become who we've never been.

I would like to thank the anonymous readers for their generous engagement and their helpful suggestions and comments. I would also like to thank Nancy Armstrong and Dierdra Reber for reading and commenting incisively on an earlier version of this essay, and Hannah Frydman for reading each of my many drafts with inexhaustible care.

${ }^{1}$ This elimination of gender indicators applies only to the protagonists, who constitute an indeterminate duo in the midst of the other gendered characters. Jeanette Winterson published her own version of an indeterminate love story with Written on the Body (1992), written in English, which is a less gendered language than French. It is unclear whether Winterson would have been aware of Garréta's work, and Written on the Body is different in its experiment of sexual indeterminacy in that only the narrator's gender is indeterminate, while the love object is identified as a married woman. 
${ }^{2}$ Garréta pronounced these strong words in English in reaction to the celebration of sexual difference that dominated both the literary and intellectual landscape of France in the 1970s and '80s by means of écriture féminine and the codification of a body of thought that came to be known as "French Feminism" in the Anglo-American academy, both of which advocate for combatting phallogocentrism through attending to and giving voice to the feminine that has been repressed by patriarchy. In other words, the dominance of the masculine and the domination wrought in its name were to be combatted through the discovery of and shoring up of the feminine as an experience and a concept. (Evidence of the artificial nature of the construct "French Feminism" can be seen in the way Monique Wittig, a fiercely anti-difference feminist, frequently gets grouped and cited along with Hélène Cixous, Julia Kristeva, and Luce Irigaray, all three philosophers of difference.) For a polemical account of the origins of French Feminism, see Christine Delphy, "The Invention of French Feminism.” For a more measured account, see Claire Goldberg Moses, "Made in America."

${ }^{3}$ There are some notable exceptions, such as Charles Dickens's Dombey and Son, where the "son" is actually a daughter, or Balzac's La Cousine Bette, where a masculine Bette takes advantage of her feminine position in order to achieve a masculine position of domination. In both cases, though, these individual aberrations only prove the rule, and the structures of social norms are preserved. I am grateful to Nancy Armstrong for drawing my attention to these examples.

${ }^{4}$ Wittig, Le Chantier littéraire, 92-102.

${ }^{5}$ Because of their political investments in the novel, Garréta and Wittig tease apart language from discourse to come up with new ways of using language, much more than other writers who do not resist the gendered machinery of the French language.

${ }^{6}$ Wittig, Le Chantier littéraire, 44.

${ }^{7}$ Wittig, "The Trojan Horse," 69.

${ }^{8}$ Garréta, “Wittig, la-langue-le-politique,” 25; my translation. Garréta's title is an echo of Wittig's Paris-la-politique (a collection of short stories). Garréta's shift from "la politique" to "le politique" is an interesting one: Wittig's title evokes a politicized Paris that is the site of political happenings, while Garréta's title evokes the political nature of language. 
${ }^{9}$ Wittig, Le Chantier littéraire, 138-39; my translation.

${ }^{10}$ Oulipo-Ouvroir de littérature potentielle, or Workshop of Potential Literature — is an experimental writing group dedicated to renewing literature by adhering to constraints. For instance, one of its most famous members, Georges Perec, wrote an entire novel, La Disparition, without using the letter $e$.

${ }^{11}$ Butler, Gender Trouble. See particularly Ch. 3, "Subversive Bodily Acts.”

12 This reading is necessarily reductive in its generality and does not account for the possibility of experiencing sexual difference in homosexual relationships, a question Judith Butler poses provocatively in "Critically Queer.”

${ }^{13}$ Garréta, Sphinx (1986), 78. All further citations will be made parenthetically, in text, with the French edition page number followed by the page number from the translation.

${ }^{14}$ Garréta, Sphinx (2015), 54-55; translation slightly modified, here and elsewhere.

${ }^{15}$ See, for example, Josyane Savigneau, “Un genre énigmatique.” Garréta, in a March 2013 interview with me, described Sphinx as a way of holding up a mirror to the reader and revealing his or her own desires, and showing how these inform and shape the experience of reading.

${ }^{16}$ While intersectional, or third-wave, feminism is often credited with calling out second-wave feminism's inattention to matters of race, the need for a feminism attentive to race and class was already being voiced by black feminists in the 1970s. See, for example, the Combahee River Collective Statement, which explicitly called attention to "the fact that the major systems of oppression are interlocking” (“Combahee River Collective Statement,” 264).

${ }^{17}$ The ' 80 s are often evoked as a racist decade, but it is worth noting that it was also the decade in which France began to develop a collective consciousness regarding matters of race, as seen in the founding of the NGO SOS Racisme in 1984.

${ }^{18}$ See Kim, Unbecoming Language: Anti-Identitarian French Feminist Fictions, which situates Garréta in a chain of influence that connects her to Wittig and Nathalie Sarraute. It shows how Sarraute, a New Novelist and modernist who is not considered in political terms, is the origin of an anti-identitarian feminist poetics that traverses the $20^{\text {th }}$ century to today through the collective corpus of these three writers. See in particular Chapter 3, "Garréta: No Subject Here," and Chapter 4, "Toward a Poetics of Unbecoming, or, Language Has a Body." 
${ }^{19}$ For example, Garréta explained to me that her 1999 novel La Décomposition was written according to multiple principles of construction, such as "a systematic transduction algorithm applied to chunks of $\grave{A}$ la recherche du temps perdu" in the text of the novel, and that many of the structuring principles of her novels are opaque and go unperceived by readers.

${ }^{20}$ Balibar, “Is There a 'Neo-Racism'?,” 22.

${ }^{21}$ Foucault, The History of Sexuality, 159.

${ }^{22}$ I imagine that Jean-Jacques Rousseau's Julie, from La Nouvelle Hélö̈se (Julie, or the New Heloise) and Denis Diderot's Sapphic Suzanne (along with the various abbesses Suzanne left in her wake), from La Religieuse (The Nun), were at the back of Garréta's mind when she killed off her narrator.

${ }^{23}$ I invoke Rancière not merely as someone who theorizes the authorial need to kill off a character, but as an intellectual touchstone for Garréta, who is interested in his philosophy of radical egalitarianism. If Garréta's work displays an affinity for Rancière's thought, it is no surprise, given her debt to Wittig. More than a decade before Rancière coined littérarité as a way of connecting the literary and the political, Wittig, in her 1986 PhD thesis at the École des hautes études en sciences sociales (EHESS) (Le Chantier littéraire, published in 2005), was already articulating a radical conception of living language as language freed, through a writerly action on and with the materiality of language, from the social meanings attached to it. This living language is theorized as the original social contract in which absolute reciprocity and equality found intersubjective relations. Wittig thus articulates the political potentiality of literature from a practitioner/artist's perspective, while Rancière approaches the question from a more abstract, philosophical point of view. See Rancière, The Flesh of Words, 108, 103. See Wittig, Le Chantier littéraire, 55-72. For more on literarity as a political operation, see Samuel Chambers, "The Politics of Literarity." ${ }^{24}$ Wittig, Le Chantier littéraire, 93. Wittig treats the Trojan horse as a sculpture and aligns it with the work of the writer precisely because the sculpture results from the sculptor's brute force and labor on its materials. Wittig sees the writer as undertaking the same work on a similarly resistant material, language. See Le Chantier littéraire, 93-98. ${ }^{25}$ Wittig, “The Trojan Horse,” 69.

${ }^{26}$ Wittig develops the notion of the straight mind at length in The Straight Mind, and it can be described, briefly, as the heterosexual social order and regime that operate by positing and replicating a fundamental, purportedly pre-social 
difference that is used to dominate any number of subcategories of human being. See especially "The Straight Mind" and "Homo Sum."

${ }^{27}$ Wittig, “The Trojan Horse,” $74-75$.

${ }^{28}$ Wittig, "The Site of Action," 100.

${ }^{29}$ My thanks to Hannah Frydman for calling my attention to this absence.

${ }^{30}$ Foucault, The History of Sexuality, 159.

Works Cited

Balibar, Étienne. “Is There a 'Neo-Racism'?” Translated by Chris Turner. In Race, Nation, Class: Ambiguous Identities, by Étienne Balibar and Immanuel Wallerstein, 17-28. New York: Verso, 1991.

Butler, Judith. “Critically Queer.” GLQ: A Journal of Lesbian and Gay Studies 1, no. 1 (1993): 17-32.

- Gender Trouble: Feminism and the Subversion of Identity. New York: Routledge, 1990.

Chambers, Samuel Allen. “The Politics of Literarity.” Theory \& Event 8, no. 3 (2005). https://muse.jhu.edu/article/187831.

Combahee River Collective. “The Combahee River Collective Statement.” In Home Girls: A Black Feminist Anthology, edited by Barbara Smith, 264-74. New Brunswick, NJ: Rutgers University Press, 1983.

Delphy, Christine. “The Invention of French Feminism: An Essential Move.” Yale French Studies, no. 97 (2000): 16697.

Foucault, Michel. The History of Sexuality: An Introduction. Translated by Robert Hurley. New York: Vintage Books, 1990.

Garréta, Anne. Sphinx. Paris: Librairie générale française, 1986.

—. Sphinx. Translated by Emma Ramadan. Dallas, TX: Deep Vellum Publishing, 2015.

—. "Wittig, la langue-le-politique.” In Lire Monique Wittig aujourd'hui, edited by Benoît Auclerc et Yannick Chevalier, 25-34. Lyon: Presses universitaires de Lyon, 2012. 
Kim, Annabel. Unbecoming Language: Anti-Identitarian French Feminist Fictions. Columbus: Ohio State University Press (forthcoming).

Moses, Claire Goldberg. "Made in America: 'French Feminism’ in Academia.” Feminist Studies 24, no. 2 (1998): 24174.

Rancière, Jacques. The Flesh of Words: The Politics of Writing. Translated by Charlotte Mandell. Stanford: Stanford University Press, 2004. Originally published as La Chair des mots : Politiques de l'écriture. Paris: Éditions Galilée, 1998.

.Why Emma Bovary Had to Be Killed.” Critical Inquiry 34, no. 2 (2008): 233-48.

Savigneau, Josyane. “Un genre énigmatique.” LeMonde.fr, April 4, 1986. http://www.lemonde.fr/archives/article/1986/04/04/un-genre-enigmatique_2917458_1819218.html.

Winterson, Jeanette. Written on the Body. London: Vintage, 1992.

Wittig, Monique. Le Chantier littéraire. Lyon: Presses universitaires de Lyon, 2010.

—. "The Site of Action.” Translated by Lois Oppenheim. In The Straight Mind, 90-100. Boston: Beacon Press, 1992.

. “The Trojan Horse.” In The Straight Mind, 68-75. Boston: Beacon Press, 1992. 